\title{
SWCS CONFERENCE Reflections on the 2013 SWCS Annual ECHOES International Conference
}

\author{
Jim Gulliford
}

nd they gathered in Reno. The 68th Annual International Conference of the Soil and Water Conservation Society met in the high desert valley Truckee Meadows at the foot of the Sierra Nevada Mountains. This fertile valley feels the pressure of urbanization and competition for limited water resources. It reminds us of one of many challenges we face: competition for the soils and water that will produce the food necessary to feed our future generations.

Resilient Landscapes, our conference theme, reflects a second compelling challenge for the future. Throughout the world, the agricultural landscape shows the scars of the tremendous pressure to produce in today's climate and economic conditions. Flood, fire, drought, and storm have shown us why conservation management decisions are as important to the farmer and rancher as seed, fertility, and pest management. We know that there is resilience in our soils, but we also know that we are pressing the limit of that resilience in far too many cases.

Dr. Gene Kelly set the stage for the conference in the Pritchard Lecture. $\mathrm{He}$ examined the vulnerability of soils to changing climate and land use conditions from across the Great Plains to the South African Savannah. If you missed the conference, visit the SWCS Web site to hear his challenging and entertaining thoughts on soil formation, utilization, and resilience. It is an essential message for our members.

Our day two plenary examined the science and practice of soil health. Opening with the lyrical "What's soil health got to do with it?" Wayne Honeycutt described the USDA Natural Resources Conservation Service soil health initiative and moderated a USDA Agricultural Research Service science panel of Jorge Delgado, Jerry Hatfield, and Jean Steiner. The panel reflected on the importance of

Jim Gultiford is executive director of the Soil and Water Conservation Society, Ankeny, lowa. soil structure, chemistry, and biology to soil health. They described conservation management and practices as tools to both protect soils and restore them. While there are limits to soil resilience, there are conservation practices that can help manage and improve soil characteristics.

The SWCS House of Delegates meeting was an important organizational activity at this year's conference. The SWCS Board of Directors President Dan Towery and the Executive Director Jim Gulliford presented a proposal the Board of Directors has developed to restructure the SWCS Board to position the Society to better serve its members and chapters and to make stronger contributions to the science, practice, and policy of resource conservation internationally. The response and comments of the delegates were helpful to the Board to both understand and address concerns of the membership. Visit the Members Only page of the SWCS Web site for a complete explanation of the reorganization proposal.

I can never say enough about the depth and quality of the workshops, symposia, general sessions, and posters that are the foundation for learning and networking each year. The Berg and Society Fellows Forum provided a balanced look at the science and environmental consequences of hydraulic fracturing. Conference participants had an opportunity for in-depth study of nitrogen management tools, leadership practices, and the use of social indicators in watershed management projects. The USDA Conservation Effects Assessment Project Rangeland Assessment and National Institute of Food and Agriculture Water Resources Research, Education, and Outreach were featured symposia sessions.

Each year, we celebrate the accomplishments of our members and partners. Jean Steiner and Robert Bird were named Fellows of the Society for their career contributions to the field of soil and water conservation, and the Hoosier Chapter received this year's Outstanding Chapter Award. We celebrated the 30th anniversary

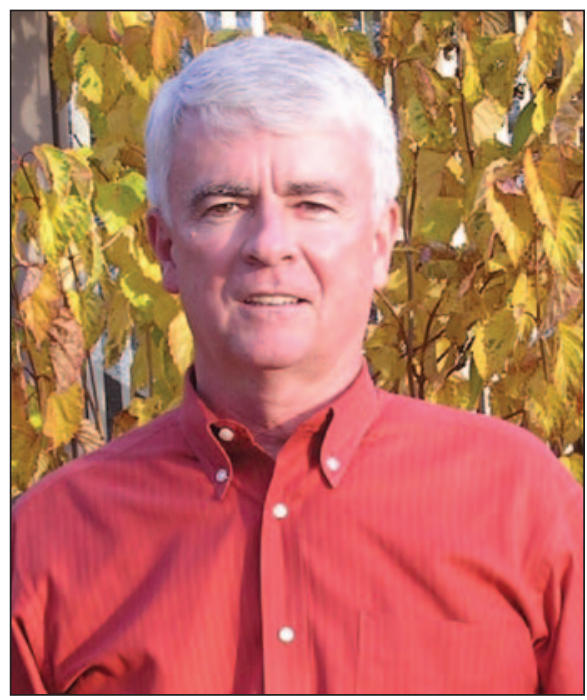

Jim Gulliford

of the Certified Professional in Erosion and Sediment Control program with conference sponsor EnviroCert International Inc. and saw an example of how that program is growing internationally.

Three outstanding tours were offered and filled this year as attendees took advantage of the opportunity to learn more about conservation programs unique to the Reno area. As I watched the busses load Wednesday morning, I heard an individual relate that for years she had heard about the importance of the snow survey program and how pleased she was to be able to visit a monitoring station and learn more about this water management tool. You can't get that experience sitting at your desk.

While each annual conference is unique, one common theme each year is the essential contribution that our planning committee, host chapter, and sponsors make to the operational success of the conference. Tommy Bass, the Program Committee Chair, and his committee did a great job preparing the program. The California-Nevada Chapter was a great host. Several members of this chapterTibor Horvath, Wendy Rash, Rob Roy, Tom Esgate- and all their volunteers provided the personal touch that makes each conference unique to the host location. DuPont Pioneer, EnviroCert International 
Inc., Monsanto, and all of our sponsors and exhibitors provided financial support and gave our participants the opportunity to learn about their products and services that support conservation on agricultural lands. Our staff and attendees can't thank you enough for those essential contributions.

Hold the date! We'll do it again next year in suburban Chicago at the Weston Lombard on July 27-30, 2014. I promise you an opportunity to learn from and interact with leading conservation researchers, practitioners, and policy makers in our field. Plan now to participate and present your work next year. 